\title{
A páncélos- és gépjármütechnikai szaktisztképzés változása az egyes képzési formák óraszámai alapján
}

\section{Changes in Specialist Officer Course Of Department Of Military Technology Modul Of Vehicles Based on the Number of Courses in Each Form of Training}

Az elmúlt két évtizedben három különböző képzési formában lettek felkészitve a páncélos- és gépjármütechnikai szaktisztek a Nemzeti Közszolgálati Egyetemen és jogelödjén a Zrínyi Miklós Nemzetvédelmi Egyetemen. A cikk a három képzési forma kreditjeinek és kontaktóraszámainak összehasonlitása révén azt vizsgálja, hogy a képzés milyen fö preferenciák alapján történt, valamint hogy az egyes képzések a bevezetésükkor milyen változásokat hoztak a szaktisztképzésben.

Kulcsszavak: gépjármütechnika, müszaki, oktatás, képzés

In the last two decades the specialist officers of department of military technology module of vehicles have been educated in the UPS and its predecessor, the Zrínyi Miklós National Defence University, according to three forms of training. This article is about the comparison of these three forms of training, and is based on the number of credits and contact courses. Furthermore, it examines the bases of the main preferences and the changes in the training of specialist officers when new courses were introduced.

Keywords: vehicle technology, technical, education, qualification

Nemzeti Közszolgálati Egyetem Hadtudományi és Honvédtisztképző Kar, egyetemi docens, e-mail: gyarmati. jozsef@uni-nke.hu, ORCID: https://orcid.org/0000-0001-7594-2383

2 Nemzeti Közszolgálati Egyetem Hadtudományi és Honvédtisztképző Kar, egyetemi docens, e-mail: vegh.robert@ uni-nke.hu, ORCID: https://orcid.org/0000-0002-9786-6702 


\section{Bevezetés}

Az elmúlt két évtizedben három képzési formában folyt a páncélos- és gépjármütechnikai szaktisztek képzése, ezek:

- gépészmérnök alapszak, gépjármütechnikai szakirány;

- had- és biztonságtechnikai mérnök alapszak, haditechnika szakirány, páncélos- és gépjármütechnikai specializáció;

- katonai logisztika alapszak, haditechnika specializáció, páncélos- és gépjármütechnikai modul.

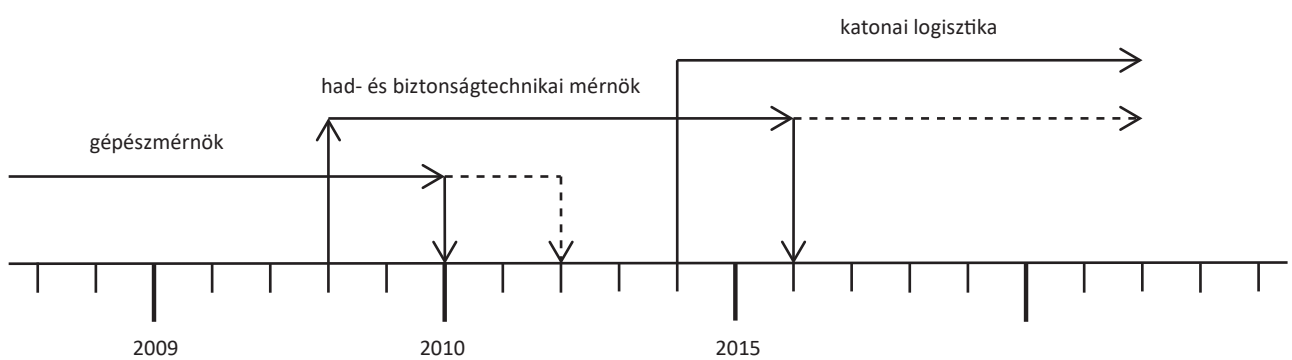

1. ábra. A vizsgált képzések bevezetésének és kifutásának ideje ${ }^{3}$

Forrás: a szerzők szerkesztése

Az egyes képzések bevezetését és kifutását mutatja az 1. ábra, amelyből jól látható az egyes képzések oktatásának az időintervalluma. Leghosszabb ideig a gépészmérnök alapszak szolgálta a gépjárműtechnikai szaktisztképzést, amelyet 2008-as bevezetéssel a had- és biztonságtechnikai mérnökképzés váltott fel. A bevezetett képzés rövid életűnek bizonyult, az utolsó beiskolázás erre a szakra 2012-ben történt, és az utolsó hadmérnök évfolyam 2016-ban végzett. Tehát mindössze öt évfolyam kapott ilyen diplomát. Az ábrán szaggatott vonal jelzi informálisan, hogy a nevezett két mérnökszak civil képzései hogyan alakultak. A gépészmérnök esetében az utolsó végzés 2012-ben történt. A had- és biztonságtechnikai mérnökképzés esetében, bár beiskolázás nincs, hallgatók még mindig vannak a biztonságtechnikai specializáción, az oktatás és a kibocsátás folyamatos.

A cikk célja, hogy az egyes képzések kontaktóráinak a vizsgálatával megállapítsa:

- a képzés szakmaspecifikusságát,

- a képzési prioritásokat,

- az általános és speciális (általános vezető vs. szaktiszt) ismeretek közötti arányt.

3 A Zrínyi Miklós Nemzetvédelmi Egyetem, gépészmérnök alapszak, gépjárműtechnikai szakirány 2004-ben érvényben lévő tanterve; Zrínyi Miklós Nemzetvédelmi Egyetem, had- és biztonságtechnikai mérnök alapszak, haditechnika szakirány, pc.- és gépjármütechnikai specializáció 2005-ben érvényben lévő tanterve; Zrínyi Miklós Nemzetvédelmi Egyetem, had- és biztonságtechnikai mérnök alapszak, haditechnika szakirány, pc.- és gépjármütechnikai specializáció 2010-ben érvényben lévő tanterve; Nemzeti Közszolgálati Egyetem, katonai logisztika alapszak, haditechnika specializáció, pc.- és gépjárműtechnikai modul 2013-ban érvényben lévő tanterve; Nemzeti Közszolgálati Egyetem, katonai logisztika alapszak, haditechnika specializáció, pc.- és gépjárműtechnikai modul 2020-ban érvényben lévő tanterve alapján. 


\section{A képzési formák összehasonlítása}

A forrás mind a három esetben a kérdéses tanterv volt. Az eltérés, ami az összehasonlítás torzításához vezethetett volna a katonai felkészítés felsőoktatási keretbe történő illesztése volt. A három képzési formánál ugyanis ezt más-más formában hajtották végre. A gépészmérnök szakon az alapkiképzést például az első szemeszter legelején hajtották végre úgy, hogy az ott kiképzéssel eltöltött egy hónap sem kreditjeinek sem pedig tanóráinak mennyisége a szak tantervében nem szerepelt. A képzés nyolc féléves volt 240 kredittel. A had- és biztonságtechnikai mérnök alapszak esetében a katonai felkészitést teljes mértékben kiejtették a felsőoktatás keretéből. A képzés hét szemeszterből állt, és az első szemesztert megelőző félévben a képzésre felvett hallgatók a felsőoktatási tanulmányaik megkezdése előtt végrehajtották a katonai felkészítésüket (alapkiképzés). Az első évfolyamra tehát már az alapkiképzésen túlesett fiatalok vonultak be. A képzés teljes kreditmennyisége a hét szemeszter miatt 210 volt. A katonai logisztika alapszak esetében nyolc féléves képzés lett kialakítva 240 kredittel, ahol az alapkiképzést az első szemeszter elején hajtották végre a honvédtisztjelöltek. Az alapkiképzés kreditesítve volt, tehát az ott elsajátított ismeretek kredittel ellátott tantárgyakkal lettek lefedve, amelyeket a képzés tantervébe illesztettek.

Az alapkiképzés három eltérő formában történő szervezése az összehasonlításokat egyrészt nehezítik, mivel a katonai ismeretek mennyisége és kreditértéke összehasonlításakor az alapkiképzést minden esetben figyelembe kell venni. A 2. ábra mutatja a képzési formák kontaktóra-mennyiségét.

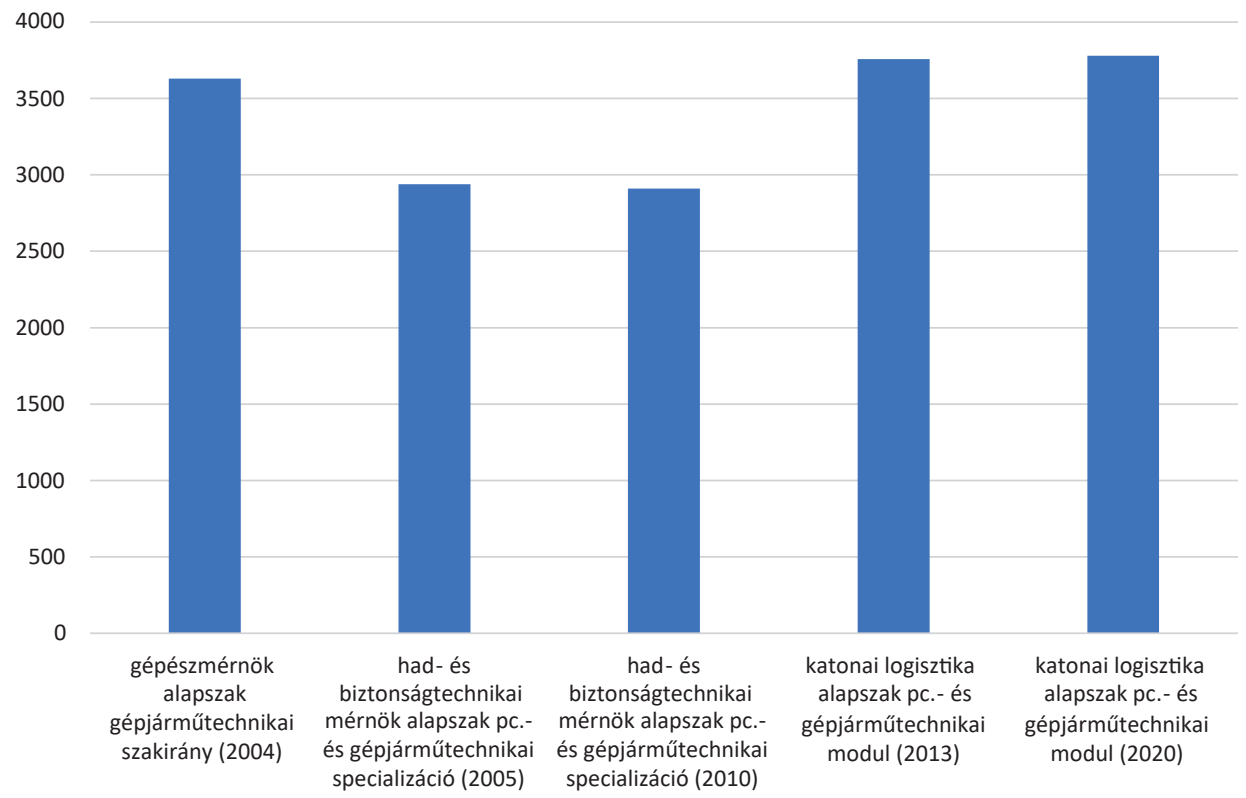

2. ábra. A különböző képzési formák kontaktóráinak mennyisége

Forrás: a szerzők szerkesztése az érvényben levő tantervek (lásd a 3. lábjegyzetben) alapján 
Az ábrán öt oszlop, ezzel együtt öt képzés különböztethető meg. Ennek az oka, hogy az egyes képzések menet közben olyan változtatásokon estek át, hogy az elkülönített vizsgálatuk indokolt. A 2. ábra összevetve az 1. ábrával nem azt jelenti, hogy ezek a szakok (had- és biztonságtechnikai mérnök, katonai logisztika) az idejük során csak egy alkalommal lettek módosítva. A vizsgálat során csak azok a változtatások lettek figyelembe véve, amelyek komolyan átalakitották a tantárgyakat és azok eloszlását. A szakokon ettől több változás volt, például a katonai logisztika esetében a 2013-as első beiskolázást követően a szak változtatásának az igénye már 2015-ben fellépett, tehát még akkor, amikor a szakon még csak az első két évfolyam volt bent, vagyis az első kibocsátás előtt két évvel.

A vizsgálat a továbbiakban, a 2. ábra szerinti öt képzési formára fókuszál, ezek:

- gépészmérnök alapszak, gépjármütechnikai szakirány 2004-ben érvényben lévő tanterve szerint;

- had- és biztonságtechnikai mérnök alapszak, haditechnika szakirány, pc.- és gépjármütechnikai specializáció 2005-ben érvényben lévő tanterve szerint;

- had- és biztonságtechnikai mérnök alapszak, haditechnika szakirány, pc.- és gépjárműtechnikai specializáció 2010-ben érvényben lévő tanterve szerint;

- katonai logisztika alapszak, haditechnika specializáció, pc.- és gépjárműtechnikai modul 2013-ban érvényben lévő tanterve szerint;

- katonai logisztika alapszak, haditechnika specializáció, pc.- és gépjármütechnikai modul 2020-ban érvényben lévő tanterve szerint.

Az összehasonlítás célja a tantárgyi struktúrák változásainak a leírása. A képzés során az oktatott tantárgyak száma 80 és 100 között mozgott, ezek összehasonlítása közvetlenül nem volt lehetséges, ezért a tárgyak a tantárgyi programokban leírt tartalmuk alapján 12 csoportba lettek beosztva, amelyet az 1. táblázat mutat.

1. táblázat. A tantárgycsoportok kialakítása

\begin{tabular}{|c|c|c|}
\hline Fsz. & Tantárgycsoport & Meghatározó tantárgyak \\
\hline 1 & Természettudományos alapismeretek & Matematika, Fizika, Kémia, Informatika \\
\hline 2 & Gazdasági ismeretek & Közgazdaságtan, Védelemgazdaságtan, Statisztika \\
\hline 3 & Humán ismeretek & Pedagógia, Pszichológia, Szociológia, Hadtörténelem \\
\hline 4 & Általános katonai ismeretek & $\begin{array}{l}\text { Harcászat, Katonai térképészet, Tereptan, Békefenntartói ismeretek, Hadijog, } \\
\text { Alapkiképzés tárgyai }\end{array}$ \\
\hline 5 & Logisztikai ismeretek & $\begin{array}{c}\text { Katonai logisztika, Csomagolástechnika, Logisztikai biztosítás, } \\
\text { Katonai szállítás }\end{array}$ \\
\hline 6 & Differenciált katonai ismeretek & Szakmai szabályzatismeret, Szakalegység vezetése \\
\hline 7 & Műszaki alapozás & $\begin{array}{c}\text { Anyagismeret, Gyártástechnológia, Géprajz, CAD, Gépelemek, Hőtan, } \\
\text { Áramlástan, Elektrotechnika, Elektronika }\end{array}$ \\
\hline 8 & Differenciált katonai-műszaki ismeretek & $\begin{array}{c}\text { Belsőégésű motorok, Járművek szerkezete, Üzemanyagellátó rendszerek, } \\
\text { Járművillamosság, Rendszerbentartás }\end{array}$ \\
\hline 9 & Szakdolgozat & \\
\hline 10 & Idegen nyelv & \\
\hline 11 & Testnevelés & \\
\hline 12 & Közszolgálati ismeretek & Közszolgálati blokk tárgyai \\
\hline
\end{tabular}

Forrás: a szerzők szerkesztése az érvényben levő tantervek (lásd a 3. lábjegyzetben) alapján 
A tantervek minden esetben tartalmaznak olyan kontaktórával rendelkező tantárgyakat, amelyekhez nem lett kredit rendelve, de ettöl függetlenül az oktatása során ismeretanyag, illetve valamilyen képesség lett átadva. Ilyen például az idegen nyelv, illetve a testnevelés, amelyek tartalma fontos a honvédtiszt felkészítésében, ezért ezek a vizsgálatba be lettek vonva. A képzések teljes kontaktóra-mennyiségei nem voltak egyforma mértékűek, ezért a pontos összehasonlításhoz nemcsak a kontaktóra összes mennyiségei, hanem annak az arányai is fel lettek használva.

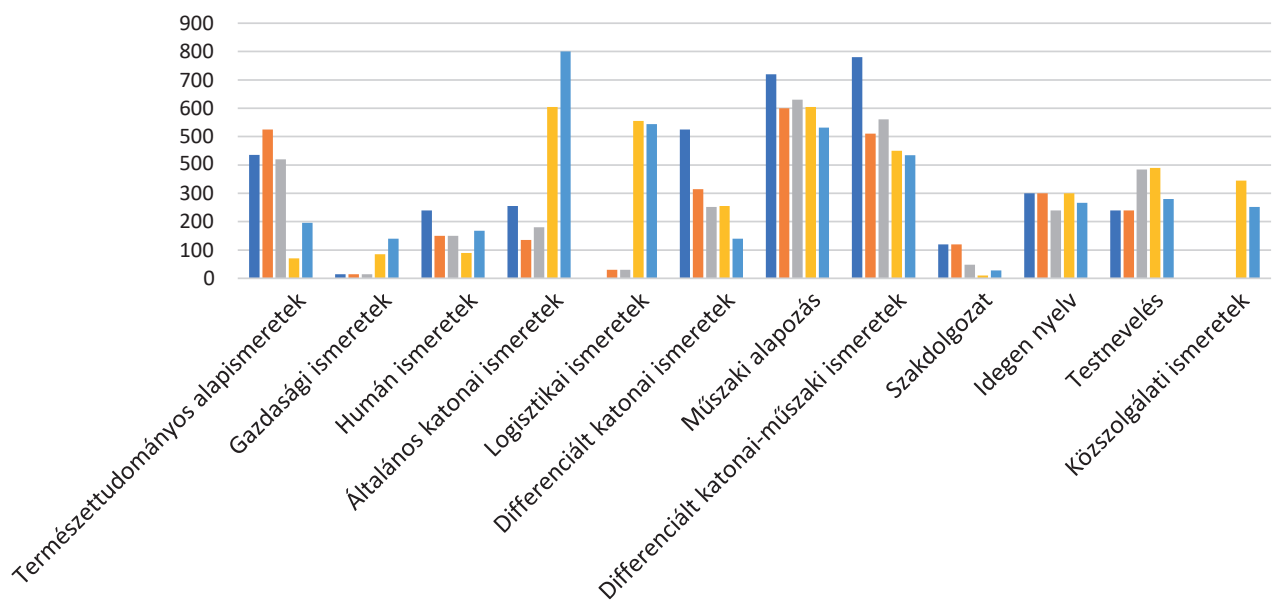

- gépészmérnök alapszak gépjármútechnikai szakirány (2004)

- had- és biztonságtechnikai mérnök alapszak pc.- és gépjármútechnikai specializáció (2005)

- had- és biztonságtechnikai mérnök alapszak pc.- és gépjármútechnikai specializáció (2010)

- katonai logisztika alapszak pc.- és gépjármútechnikai modul (2013)

- katonai logisztika alapszak pc.- és gépjármútechnikai modul (2020)

3. ábra. A vizsgált képzési formák tanulmányi terület szerinti óraeloszlása

Forrás: a szerzők szerkesztése az érvényben levő tantervek (lásd a 3. lábjegyzetben) alapján

A 3. ábra alapján megállapítható, hogy a természettudományos alapozás az egymást követő képzések során egyre kevesebb óraszámot kapott. Különösen alacsony a katonai logisztika alapszak természettudományos alapozása a szak eredeti 2013-as tanterve szerint. A korábbi képzésekhez képest megszűnt a fizika és a kémia oktatása, csak a matematika maradt meg, az is nagyon kis óraszámban. Az óraszámcsökkenés a mérnökképzés megszűnésével magyarázható. A logisztika minimális matematika oktatását igényelte, amivel a logisztika müszaki területeinek (pc.- és gépjármű) is meg kellett elégedniük. Ezzel párhuzamosan a gazdasági területek oktatását a logisztika jobban igényelte, így ezek óraszáma a logisztika alapszak bevezetésével jelentősen növekedett. Nincs trendszerű változás a humán ismeretek területén, az általános katonai ismereteknél viszont jelentős növekedés látható. Az első két képzési forma viszont nem tartalmazza az alapkiképzés hosszát és annak a tantárgyi programokban való elhelyezését, a kép tehát ennél árnyaltabb. A gépészmérnök szak esetében, amely jelentősebb óraszámmal rendelkezik, mint 
a had- és biztonságtechnikai mérnök, egy hónapos volt az alapkiképzés, és ennek tartalma nincs megjelenítve a tantárgyi programban. A had- és biztonságtechnikai mérnök esetében a legkisebb óraszám látható, viszont itt egy lényegesen hosszabb alapkiképzést kaptak a hallgatók, ami szintén nem szerepel a tantárgyi programban, ezzel együtt a 3. ábrában sem. A logisztika alapszak esetében a had- és biztonságtechnika mérnökképzéshez hasonlóan három hónapos alapkiképzést kaptak a hallgatók (honvédtisztjelöltek), ami viszont része a tantárgyi programnak. A szak 2020-as változatában tovább nő az általános katonai ismeretek mennyisége, viszont itt egy rajparancsnoki képzés is belekerült a tantervbe.

Figyelembe véve a leírtakat az egymást követő képzések esetében, az általános katonai kiképzés egyre fontosabb részét képezte a tisztképzésnek, bár a mérték a 3. ábrán láthatóhoz képest kisebb mértékben növekedhetett.

A logisztikai ismeretek óraszáma egyértelmű és jelentős növekedést mutat. A gépészmérnök szaknál nincs ilyen ismeret, a had- és biztonságtechnikai szaknál kismértékben szerepel, míg a logisztika szak esetében jelentős óraszámot kapott. Az egyes szakokon belüli változás mértéke elhanyagolható.

A differenciált katonai ismeretek esetében fordított a kép. A hallgatók (honvédtisztjelöltek) egyre kevesebb órát kaptak ebből. Az igény a speciális felkészítésből az általános irányába tolódott. A tantárgyi programok kialakítása során a speciális ismereteket, ami az első beosztás betöltéséhez szükséges, kevésbé fontosnak ítélték meg, mint az általános logisztikai ismereteket.

Nincs trendjellegű változás az idegennyelv-oktatásra és a testnevelésre fordított óraszámok tekintetében. A katonai logisztika alapszak esetében új ismeretanyagként jelenik meg a közszolgálati ismeretek.

A 3. ábra összóraszámot mutat, viszont a prioritások vizsgálatához pontosabb kimutatást ad a tantárgyakra fordított oktatási idő százalékos arányainak a bemutatása. A 4. ábra mutatja a tárgyak százalékos megoszlását a vizsgált képzési formáknál.

A 4. ábrán látható százalékos eloszlással azt lehet vizsgálni, hogy az egyes képzéseken belül milyen prioritást élveztek az egyes tantárgycsoportok.

Természettudományos ismeretek esetében jóval nagyobb különbséget láthatunk a gépészmérnök és a had- és biztonságtechnikai mérnök között a hadmérnök javára, ha a százalékos eloszlást (4. ábra) figyeljük meg. A had- és biztonságtechnikai képzésben tehát a természettudományos ismeretek nagyobb prioritást élveztek, mint azt az óraszámok közötti különbség (3. ábra) mutatja.

A müszaki alapozás tantárgyainak esetében, a gépészmérnöki képzésben nagyobb óraszám látható, mint a had- és biztonságtechnikai mérnökképzésben (3. ábra). Viszont a százalékos kimutatásnál ez nagyobb részarányt képvisel, amiből következik a nagyobb prioritás. 


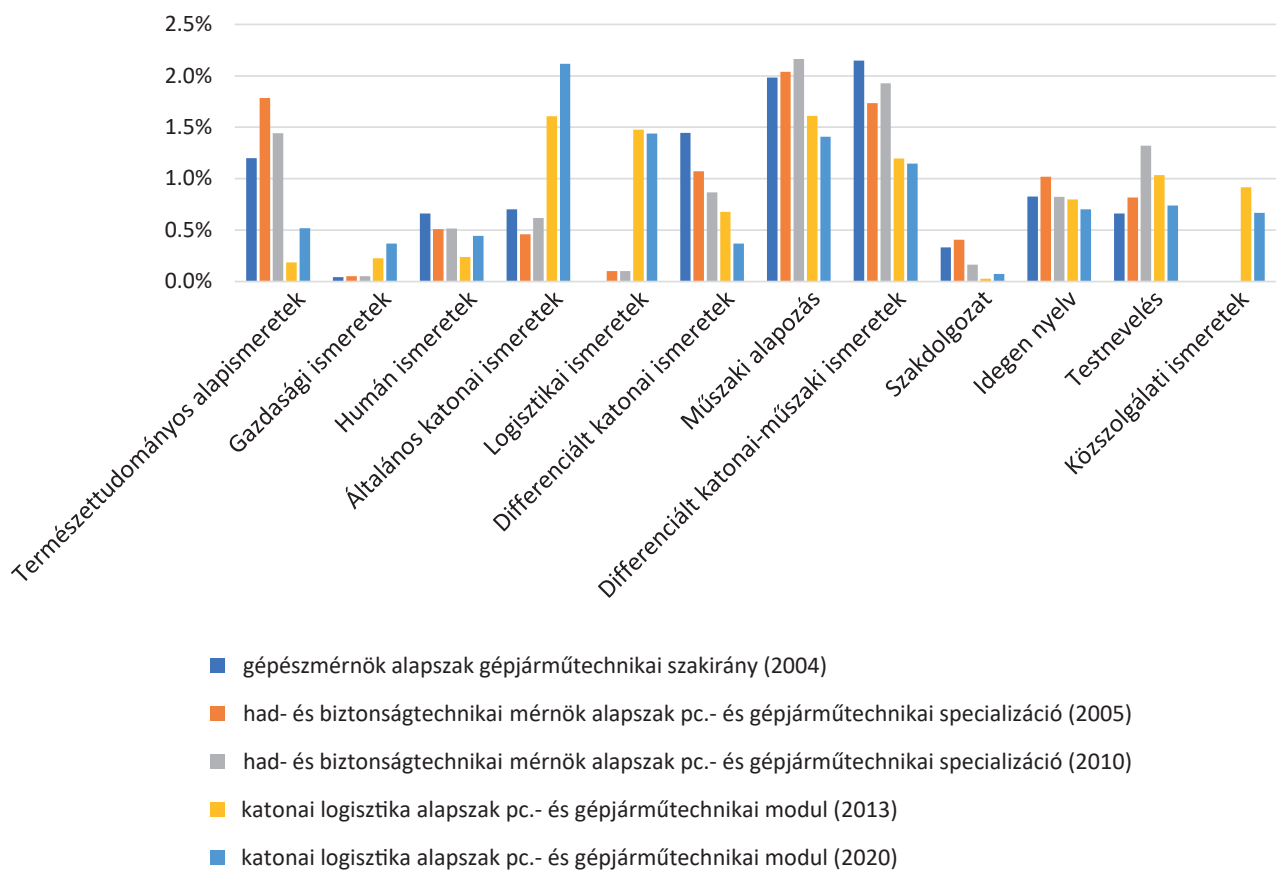

4. ábra. A vizsgált képzési formák tanulmányi terület szerinti százalékos óraeloszlása Forrás: a szerzők szerkesztése az érvényben levő tantervek (lásd a 3. lábjegyzetben) alapján

Az egyes tantárgycsoportok prioritásának változását Pareto-elemzés segítségével lehet megítélni. A Pareto-elemzés az egyes képzési formák tantárgycsoportjainak százalékos eloszlását csökkenő sorrendben ábrázolja. Az elemzés eredményeit az 5., 6., 7., 8. ábrák mutatják. Az elemzés jól áttekinthetősége érdekében a gépjármütechnikai szakismereteket tartalmazó és az azokat megalapozó tantárgycsoportok (Természettudományos alapismeretek, Műszaki alapozás, Differenciált katonai ismeretek, Differenciált katonai-műszaki ismeretek) vízszintes sraffozással lettek jelölve. Az ezen oszlopok elhelyezkedése a prioritási sorrendben jól mutatja a képzés szakmaspecifikus jellegét. 


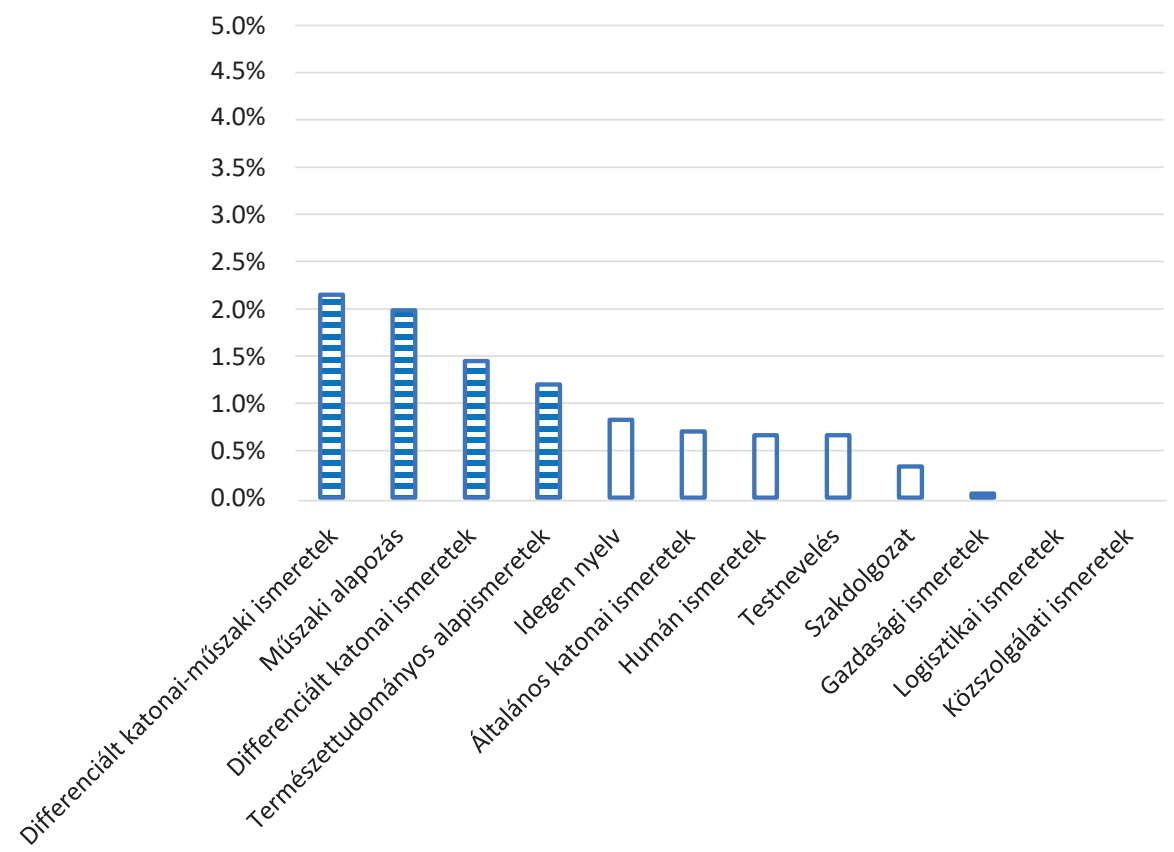

5. ábra. A gépészmérnök alapszak, gépjárműtechnikai szakirány tantárgycsoportjainak Pareto-elemzése

Forrás: a szerzők szerkesztése a Zrínyi Miklós Nemzetvédelmi Egyetem, gépészmérnök alapszak, gépjárműtechnikai szakirány 2004-ben érvényben lévő tanterve alapján

Az 5. ábrán jól látható, hogy a szakmaspecifikus tantárgycsoportok az első négy helyet foglalják el, és összességében a képzés 67,8\%-át teszik ki. A képzés rendelkezik alapprioritással, ez pedig a pc.- és gépjárműtechnikai szaktiszt képzése. Az első beosztás az elmúlt évtized tapasztalatai szerint túlnyomó többségében szakmai, föleg javító szakaszparancsnok, ezért ez a képzési forma az első tiszti beosztásra való felkészítést a szakmai képzéssel párhuzamosan is elsődlegesen célozta. ${ }^{4}$

4 Sebők István-Tar Csaba: A katonai alapképzési szak fegyverzettechnikai moduljának felépítése a korábbi képzések tükrében, a szakmai tantárgyakra fordított óramennyiség szemszögéből. Bolyai Szemle, 25. (2016), 3. 11-19. 


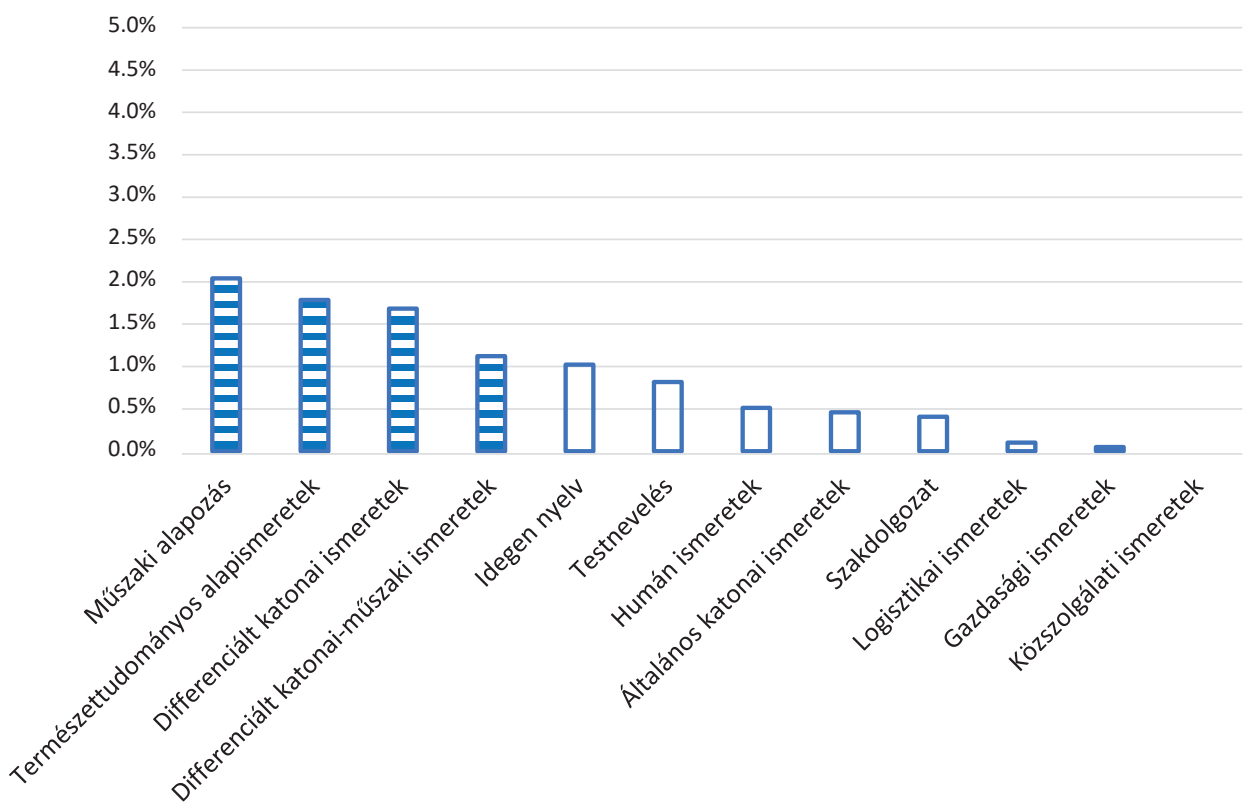

6. ábra. A had- és biztonságtechnikai mérnök alapszak, haditechnika szakirány, pc.- és gépjármütechnikai specializáció (2005) tantárgycsoportjainak Pareto-elemzése

Forrás: a szerzők szerkesztése a Zrínyi Miklós Nemzetvédelmi Egyetem, had- és biztonságtechnikai mérnök alapszak, haditechnika szakirány, pc.- és gépjármütechnikai specializáció 2005-ben érvényben lévő tanterve alapján

A had- és biztonságtechnikai mérnökképzés esetében a szakmaspecifikus tantárgycsoportok a gépészmérnökképzéshez hasonlóan az első négy helyet foglalják el, és összességében a képzés $66 \%$-át teszik ki. Viszont figyelembe kell venni, hogy ez a százalék a hét tanulmányi félév miatt kevesebb óraszámot jelent, de az is kijelenthető, hogy a had- és biztonságtechnikai mérnökképzésnél a szakképzés preferenciája nem csökkent. A szakmaspecifikus tárgyak sorrendje viszont változott a gépészmérnökképzés esetében, a differenciált katonai-műszaki ismeretek a képzés elsődlegesen preferált ismeretanyagát képezte (21\%), a had- és biztonságtechnikai mérnökképzés esetében pedig ez már csak a negyedikként preferált ismeretanyag (11\%). Ez a nevezett tantárgycsoport preferenciájának az erős csökkenését jelzi, ami a kontaktóra mennyiségének a csökkenéséből (3. ábra) is látható. 


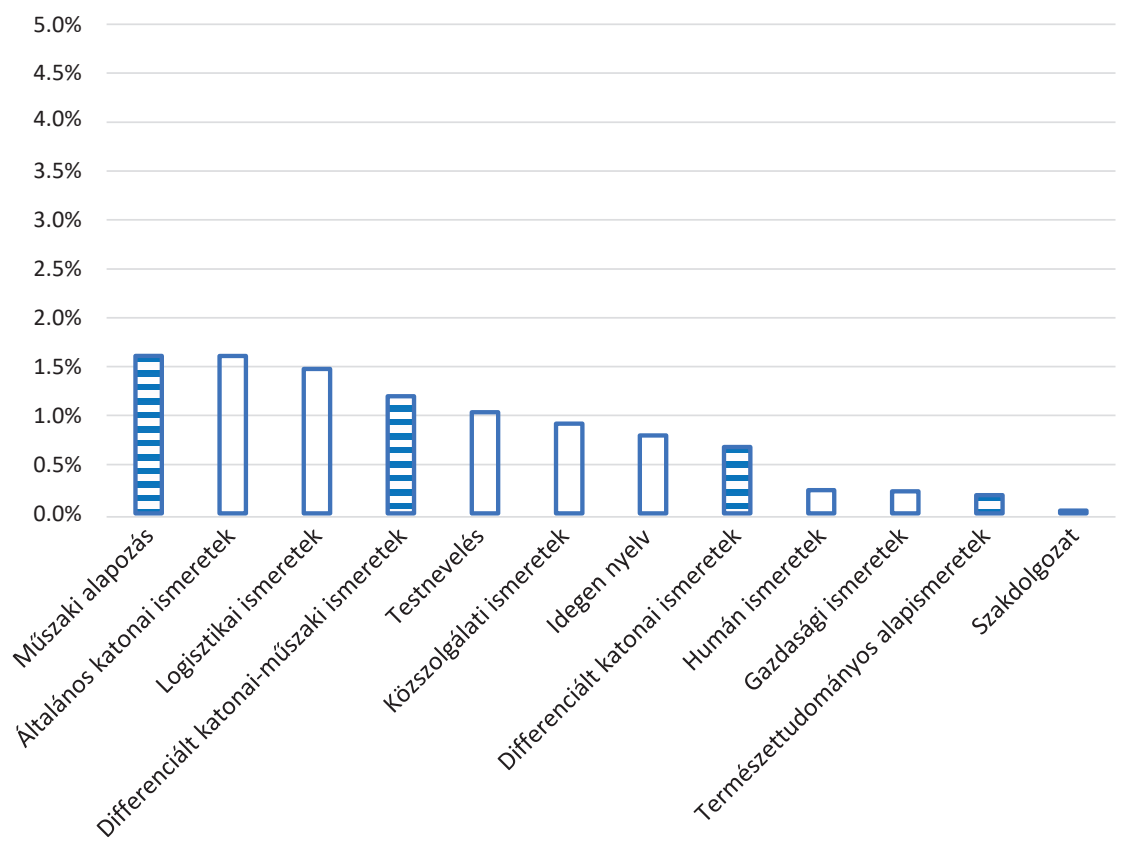

7. ábra. A katonai logisztika alapszak, haditechnika specializáció, pc.- és gépjárműtechnikai modul (2013) tantárgycsoportjainak Pareto-elemzése

Forrás: a szerzök szerkesztése a Nemzeti Közszolgálati Egyetem, katonai logisztika alapszak, haditechnika specializáció, pc.- és gépjármütechnikai modul 2013-ban érvényben lévő tanterve alapján

A katonai logisztika alapszak esetében lényeges változást lehet tapasztalni. A szakmaspecifikus tárgyak aránya 37\%-ra csökkent, és bár a müszaki alapozás a legpreferáltabb, de minimális mértékben. Jelentős mértékben megnőtt az általános jellegű ismeretek aránya, vagyis az általános katonai ismeretek és a logisztika ismeretek, amelyek összesen 30\%-os aránnyal rendelkeznek. Ez az arány jelentős ugyan, de nem olyan mértékben, hogy meghatározóvá váljon. A képzésnek elveszett a meghatározó célja, az általános és a specifikus képzés között egyensúlyozott. 


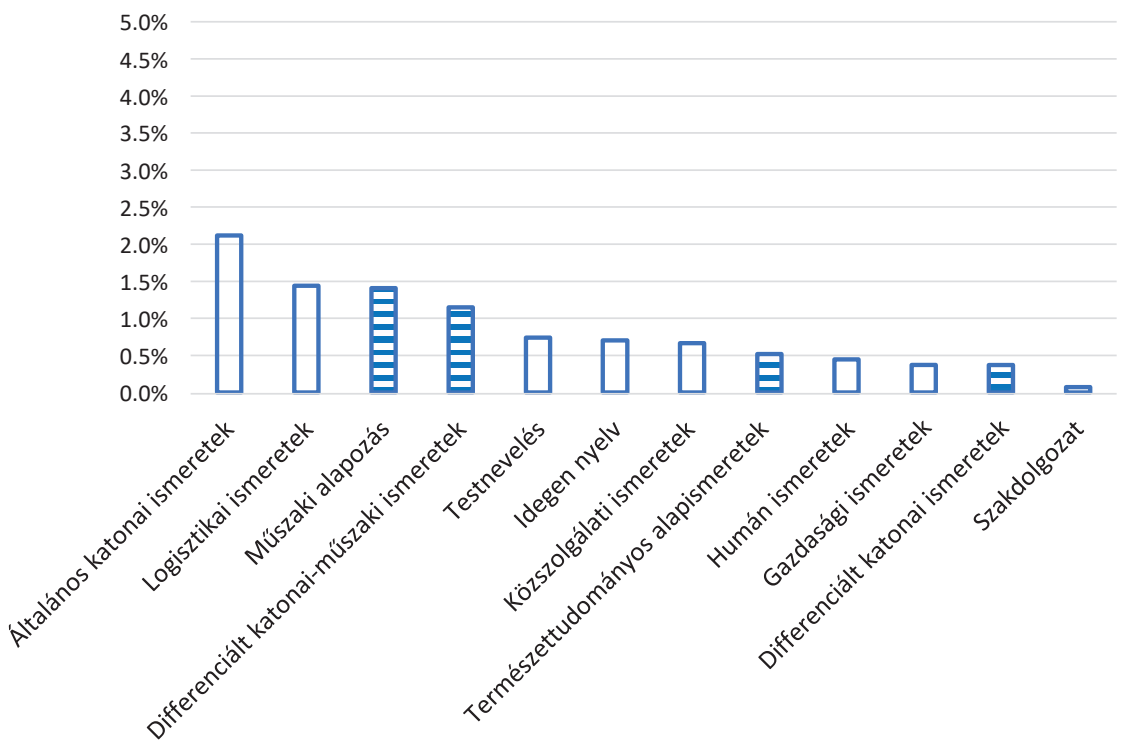

8. ábra. A katonai logisztika alapszak, haditechnika specializáció, pc.- és gépjármütechnikai modul (2020) tantárgycsoportjainak Pareto-elemzése

Forrás: a szerzők szerkesztése a Nemzeti Közszolgálati Egyetem, katonai logisztika alapszak, haditechnika specializáció, PC.- és gépjármütechnikai modul 2020-ban érvényben lévő tanterve alapján

A katonai logisztika alapszak 2020-as változtatásával a szakmaspecifikus tárgyak aránya 34\%-ra csökkent (8. ábra). Az általános katonai ismeretek és a logisztika 34\%-ra nőtt, a változás nem jelentős, tehát a szakmai tárgyak kissé alacsonyabb preferáltságával marad az a helyzet, hogy a képzés a változtatással sem találta meg a fő irányvonalát.

\section{3. Összegzés}

A cikk a bevezetésben leírtak szerint nem célozza meg az új képzések bevezetésének körülményeit, és nem próbálja feltárni azok céljait. A cél a változás leírása deskriptív statisztikai eszközökkel, és ezek alapján következtetések megállapítása.

A 1. ábra alapján megállapítható, hogy a gépészmérnök szak 1990-es években történő bevezetésével és a 2010-es kifutásával a legtovább alkalmazott szak volt a pc.- és gépjármütechnikai tisztképzésben. A képzés alapprioritása a tantárgyak és azok óraszámai során a szaktisztképzés volt. Rendkívül magas óraszámot kaptak azokból az ismeretekből, amelyeket a hallgatók az első tiszti beosztásban felhasználtak. A képzés a szakmai, ezen belül a müszaki képzésre koncentrált, megteremtve a müszaki területen való továbbtanulás lehetőségét. A képzés további előnye, hogy azt az ismeretanyagot, vagyis a müszaki ismereteket preferálta, ami a tapasztalat szerint a szakmai pályafutás során önállóan nem elsajátítható. A képzés célirányossága olyan szakmai 
felkészültséget és hátteret adott a hallgatóknak, amelyre a szakmai pályafutás során további szükséges ismeret már önállóan elsajátítható volt. ${ }^{5}$

A had- és biztonságtechnikai mérnökképzés a kevesebb óraszámot figyelembe véve hasonló prioritásokkal rendelkezett. A szűkebb keretei között megtartotta a célirányosságát. A különbség, hogy a differenciált katonai-műszaki ismeretanyag óraszámának jelentős csökkenése kevésbé készítette fel az első beosztásra, amely alapvetően javító szakaszparancsnok volt.

A katonailogisztika-képzésen belüli pc.- és gépjárműtechnikai tisztképzés az előző kettőhöz képest jelentős eltérést mutat. A szakmai tárgyak óraszámcsökkenése jelentős. A szakmai tárgyak aránya felére esett vissza korábbi két képzéshez képest. Ennek megfelelően a képzés elveszítette a fö prioritását, az általános és a specifikus képzés között egyensúlyoz.

\section{Felhasznált irodalom}

Nemzeti Közszolgálati Egyetem, katonai logisztika alapszak, haditechnika specializáció, páncélosés gépjármütechnikai modul 2013-ban érvényben lévő tanterve

Nemzeti Közszolgálati Egyetem, katonai logisztika alapszak, haditechnika specializáció, páncélosés gépjármütechnikai modul 2020-ban érvényben lévő tanterve

Sebők István - Tar Csaba: A katonai alapképzési szak fegyverzettechnikai moduljának felépítése a korábbi képzések tükrében, a szakmai tantárgyakra fordított óramennyiség szemszögéből. Bolyai Szemle, 25. (2016), 3. 11-19.

Sebők István: A fegyver- és fegyverzettechnikai szakemberek oktatásának, képzésének vizsgálata az új elvek és irányok tükrében. Seregszemle, 16. (2018), 1. 57-62.

Zrínyi Miklós Nemzetvédelmi Egyetem, gépészmérnök alapszak, gépjárműtechnikai szakirány 2004-ben érvényben lévő tanterve

Zrínyi Miklós Nemzetvédelmi Egyetem, had- és biztonságtechnikai mérnök alapszak, haditechnika szakirány, páncélos- és gépjármütechnikai specializáció 2005-ben érvényben lévő tanterve

Zrínyi Miklós Nemzetvédelmi Egyetem, had- és biztonságtechnikai mérnök alapszak, haditechnika szakirány, páncélos- és gépjármütechnikai specializáció 2010-ben érvényben lévő tanterve 